\title{
Women Leaders' Transformational Leadership Characters: a Case Study at An Islamic University
}

\author{
Mukhlisah, \\ Universitas Negeri Surabaya \\ Surabaya Indonesia \\ Mukhlishah.bki@gmail.com
}

\begin{abstract}
The study aimed at revealing the tendency of transformational leadership characters performed or owned by women leaders at an Islamic University of Sunan Ampel Surabaya, East Java, Indonesia. The study used a qualitative approach within case study design. The data of the study were collected through observation and interview. The study showed that firstly, there were seven characters of transformational leadership consisting of being everlasting learners, being brave, being agents of change, having capacity to think of complexity, uncertainty, and ambiguity, being value performer, trusting other people, and performing visionary behavior. Secondly, there were also the supporting factors of the growth of those characters such as academic status or achievements, communication competence, social interaction capacity, negotiation ability, and analysis skill. In short, there was a tendency of being the value performer character which was supported by the social interaction capacity owned by the women leaders at the university. This was affected by the existence of the religious values developed by mostly women leaders in leading the Islamic university.
\end{abstract}

Keywords-Transformational leadership, women leaders, Islamic university

\section{INTRODUCTION}

The existence of women leaders at Islamic universities remains polemic and hot discussion in society in Indonesia. One of the factors causing the phenomena above is the contribution of Islam as mostly embraced religion by Indonesian women which gives some directions not to promote women to be the leaders in organisations or universities.

In Islamic concepts, an individual leader is expected to be performed by men. It is because man is supposed to have better and bigger potential and capacity to lead rather than woman. In other words, women are assumed to have some weaknesses known as 'Cinderella complex' [1] In this case, woman is often identified by the condition of being incapable and dependent to man's power. Hence, women's roles are often under controlled by men in all aspects.

However, the 'marginal' status belonging to women has changed and decreased recently. The emergence of women move aimed at getting similar rights and positions between man and woman known as 'gender similarity'.
[2] states that gender similarity is known as a concept to pose women and men to have similar rights and positions in order to make women be able to actualize and play their roles in the world by keeping their own nature. It means that there is no more differences needed to be conflicted between men and women in relation to get similar opportunities, rights and positions in leading organisations or institutions without breaking their nature regulations.

The phenomena of the gender similarity also happen in some universities with no exceptions. Nowadays, some women have been successful to be leaders in universities. This shows that society and academicians have realized about women's roles and functions in universities.

However, the emergence of women leaders in universities entails some questions in relation to the patterns of leadership performed by them. This is because women are assumed to have various or different characters from men. Those certain characters will influence to the implementation of the leadership pattern and the journey of leading the universities done.

As known that being a leader is not easy, but has a big responsibility to the organisations or universities lead. [3] explains that leadership is an ability owned by people to give some influences and support other people in order to be able to do something together. In line with Yukl, [4] also defines leadership as an effort to reach success together by giving the influence and motivation to other people to do similar things together.

There are several types of leadership that can be performed by women leaders. Each woman leader has their own tendency to perform one of the leadership types. It will depend on their certain characters owned. Regarding the information above, the transformational leadership has become the most chosen type by the women leaders in universities. One of the factors causing the phenomena is that the transformational leadership type may give important role to the increase of staff's commitment and proficiency [4]. Those roles are done by giving the opportunities to each individual to get involved in various activities.

Commitment and proficiency are the keys to get the success and development for universities. Every individual is 
expected to have good commitment and proficiency. Those two things can be seen from the way how they work and get involved in some activities. Therefore, the most important thing is that how the leaders can give support and opportunities for each individual to get involved in some activities held.

The acts of giving opportunities are easy to be done. It depends on certain characters belonging to each leader. However, the women leaders are often capable of performing their capacities to lead other people to get involved in participating some activities held. This also indicates that those women leaders have implemented the transformational leadership pattern in leading the organisations or universities.

This phenomenon emerges in one of the Islamic universities in Indonesia known as State Islamic University of Sunan Ampel Surabaya. In short, what happens at UINSA shows a depiction of the women leaders' tendencies to implement the transformational leadership pattern. This is also supported by their specific characters such as being everlasting learners, being brave, being agents of change, having capacity to think of complexity, uncertainty, and ambiguity, being value performer, trusting other people, and performing visionary behavior [5]

There are various factors supporting the growth of those characters like academic status or achievements, communication skills, social interaction capacities, negotiation competencies, and analysis skills.

With a reference to the information above, the study aims to analyze the supporting factors of the implementation of the transformational leadership pattern performed by the women leaders at UINSA. Then, to get the focus of the study, the writer formulated some research questions as follows. 1. What characters are grown by the women leaders to implement the transformational leadership patter in leading the management of Islamic university? 2. What factors support the growth of the characters owned in the implementation of the transformational leadership pattern to manage the Islamic university?

\section{METHOD}

This study used a qualitative approach within case study design. All events and realities related to the implementation of the transformational leadership patterns within specific characters and factor supporting the growth of the characters were analyzed, interpreted, and described to get thick and natural information [6]

The study was done at UINSA. Specifically, the study involved an educational faculty consisting of seven departments. In this case, there were seven women leaders were included to be the representative participants of the study from each faculty.

The data of the study were obtained through observation and interview. In doing the interview, the writer did or applied in-depth interview activity. Meanwhile, in doing the observation, the writer did or applied non-participant observation. [7] In detail, the interview was done by giving some prepared and modified questions to the participants directly (face-to-face) in turn. All statements given by the participants were recorded with a camera recorder. Meantime, in doing the observation, the writer prepared some fieldnotes to write all things happened to answer the focuses of the study.

\section{RESULTS AND DISCUSSION}

In implementing the leadership journey, the women leaders of UINSA performed the transformational leadership pattern. This pattern of the leadership, generally, was in accordance with their specific characters such as being everlasting learners (Eveler), being brave (Brav), being agents of change (Acheng), having capacity to think of complexity, uncertainty, and ambiguity(Cacua), being value performer (Vaper), trusting other people (Truspe), and performing visionary behavior (Persib).

TABLE 1: Transformational leadership characters performed by the UINSA women leaders (In Numbers)

\begin{tabular}{|c|c|c|c|c|c|c|c|c|}
\hline $\begin{array}{c}\text { Character } \\
\text { Type }\end{array}$ & \multicolumn{6}{|c|}{ Women Officials } & \multirow{2}{*}{ Total } \\
\cline { 2 - 7 } & 1 & 2 & 3 & 4 & 5 & 6 & 7 & \\
\hline Eveler & 1 & 1 & 1 & - & 1 & 1 & - & 5 \\
Brav & 1 & - & 1 & 1 & 1 & 1 & 1 & 6 \\
Acheng & - & 1 & 1 & 1 & 1 & - & 1 & 5 \\
cacua & - & - & - & 1 & - & 1 & - & 2 \\
Vaper & 1 & 1 & 1 & 1 & 1 & 1 & 1 & 7 \\
Trsupe & 1 & 1 & 1 & - & 1 & 1 & 1 & 6 \\
Persib & 1 & 1 & - & 1 & - & - & 1 & 4 \\
& & & & & & & & \\
& 5 & 5 & 5 & 5 & 5 & 5 & 5 & 35 \\
\hline
\end{tabular}

Overall, the table above shows that the character of being the value performer (Vaper) was known to be the most dominant character owned, grown, or performed by the UINSA women leaders with the score total 7 of 35 . Eventhough each individual women leader investigated had different backgrounds, economic status, and surrounding environment where they lived. Those things did not give significant effects to influence or form their tendencies to perform the character of being the value performer.

What happened to the women leaders showed one desire to give the influence to other people or followers through their good personalities taken from the implementation of the religion and local culture concepts.

The table above also shows that the least character perfomed by the UINSA women leaders was the character of having the capacity to think of complexity, ambiguity, and uncertainty with the score total 2 of 35 . This indicates that the women leaders had a weakness of doing the complicated or sophisticated jobs. This also became the trend that they way they worked tended to connect more with the relationship orientated rather than task. This was known as relationshiporientated leadership [8] 
The relationship-orientatied leadership tended to work with togetherness in accomplishing any jobs or problems. This style of leadership did not like to be responsible personally. But the leaders needed other people or parties to get the responsibilities for any jobs done. This was caused by the weakness they had especially when it was concerned with their physics.

Meanwhile, the second table below shows the vraieties of factors supporting the growth of the characters of the treanformational leadership mentioned. Those factors were like academic status or achievements (Acas), communication competence (Com), social interaction capacity (Inter), negotiation ability (Nego), and analysis skill (Anas).

What happened to the factors supporting the growth of the characters of the transformational leaderships performed by the women leaders of UINSA showed that the capacity if holding or building the social interactions became the most supporting factor with teh score total 7 of 27.

This strengthened the evidence about the growth of the women leaders' character of being the value performer above. The character of being the value performer imlplicated to the emergence of the social interaction capacity. This was because within the character of being the value performer, the women leaders afforded to change their personalities to be more polite, religious, and culturally behaved. Those things could be seen from their success in holding the social interactions with other people or their followers. The better the capacity of holding or building the social interactions they had, the more the desire to perform their good personalities they had, so that they could become the good model or persons or leaders to be followed by other people.

Meantime, the least supporting factor to the growth of the characters of the transformational leadership perfomed by the UINSA women leaders went to the analysis capacity with the score total 4 of 27 . This also indicated that the UINSA women leaders had the weakness of using their logical thinking process.

In doing the analysis, the use of logical thinking process is very crucial to get the solutions for each problem faced accurately. But, what happened was that the UINSA women leaders tended to use their feelings in vocalizing or voicing their opnions. This also strengthened the least point of the character of having the competence in thinking about complex, uncertain, and ambiguous matters.

TABLE 2: Factors supporting the growth of the characters of the transformational leadeship performed by the UINSA women leaders (In Numbers)

\begin{tabular}{|c|c|c|c|c|c|c|c|c|}
\hline $\begin{array}{c}\text { Character } \\
\text { Type }\end{array}$ & \multicolumn{6}{|c|}{ Women Officials } & \multirow{2}{*}{ Total } \\
\cline { 2 - 8 } & 1 & 2 & 3 & 4 & 5 & 6 & 7 & \\
\hline Acas & 1 & - & 1 & 1 & 1 & - & 1 & 5 \\
Com & 1 & 1 & 1 & - & 1 & 1 & 1 & 6 \\
Inter & 1 & 1 & 1 & 1 & 1 & 1 & 1 & 7 \\
Nego & - & 1 & 1 & 1 & 1 & 1 & - & 5 \\
Anas & 1 & 1 & - & 1 & - & - & 1 & 4 \\
& & & & & & & & \\
& 4 & 4 & 4 & 4 & 4 & 3 & 4 & 27 \\
\hline
\end{tabular}

\section{CONCLUSION}

One important thing which could be concluded in this study was that the implementation of the transformational leadership patterns performed by the women leaders at UINSA needed to be supported by certain or personal characters and competences. This was because the transformational leadership pattern could not grow by itself automatically. But it required some acts of nourishing and practicing certain training to implant the supporting characters and competences.

The results of the study revealed the tendencies of the women leaders in UINSA to grow a certain character known as being the value performer. This character afforded to support the women leaders to entail a good model of being leaders which could attract other people's sympathy to the leadership journey style performed. However, the growth of character of being the value performer needed to be supported by the capacities in holding or building social interactions. This could be an access to grow a good personality of being successful and honorable leaders.

\section{References}

[1] D. Colette, "The Cinderella complex: Women's hidden fear of independence." New York: Summit Books, 1981.

[2] R. N. Dwijowijoto, Gender dan strategi pengarus-utamaannya di Indonesia. Pustaka Pelajar, 2008.

[3] D. I. Jung and J. J. Sosik, "Transformational leadership in work groups: The role of empowerment, cohesiveness, and collective-efficacy on perceived group performance," Small Gr. Res., vol. 33, no. 3, pp. 313 336, 2002.

[4] T. Bush, "From management to leadership: semantic or meaningful change?," Educ. Manag. Adm. Leadersh., vol. 36, no. 2, pp. 271-288, 2008.

[5] M. A. Devanna and N. Tichy, "Creating the competitive organization of the 21st century: The boundaryless corporation," Hum. Resour. Manage., vol. 29, no. 4, pp. 455-471, 1990.

[6] L. Cohen, L. Manion, and K. Morrison, Research methods in education. Routledge, 2002.

[7] R. Bogdan and S. Biklen, "Qualitative research for education: An introduction to theory and practice," Needham Height. MA Allyn Bacon, 2007.

[8] A. H. Eagly and B. T. Johnson, "Gender and leadership style: A metaanalysis.," Psychol. Bull., vol. 108, no. 2, p. 233, 1990.

[9] A. Copeland, A. Martin, and M. Walker, "Repo runs: Evidence from the tri-party repo market," J. Finance, vol. 69, no. 6, pp. 2343-2380, 2014

[10] J. B. Brown, "The building of a virtuous transformational leader," $J$. Virtues Leadersh., vol. 2, no. 1, pp. 6-14, 2011. 